\title{
METHODOLOGICAL TOOLS FOR ASSESSING THE LEVEL OF STABILITY OF THE REGIONS OF THE SOUTHERN AND NORTH CAUCASUS FEDERAL DISTRICTS OF RUSSIA
}

\author{
Misak S. Arzumanyan \\ Krasnoyarsk State Agrarian University, Krasnoyarsk, Russian Federation
}

\begin{abstract}
Thanks to the main political documents adopted at the UN world summit on the environment and development in Rio de Janeiro in 1992, the development of the sustainable development system in Russia has been intensified. In the Russian Federation, the transition to sustainable development continues through the logical transformation of traditional systems into capitalist ones. In view of the variety of differences in the socio-economic development of regions differentiated by federal districts, it becomes relevant to develop methods for determining (evaluating) the levels of stability of territorial entities. Many researchers usually group sustainability criteria (indicators) in the context of economic, social and environmental components. The purpose of the article is to determine the level of stability of the regions of the Southern and North Caucasus Federal Districts of Russia by quantifying their potential. The article uses mathematical methods to quantify the components of regional stability (potential) based on five factors of stability: economic, political, environmental, social and institutional. The criteria for determining the levels of regional stability are established. The most stable regions (subjects) of the Southern and North Caucasus Federal districts of Russia - Rostov and Volgograd regions, Krasnodar and Stavropol krais have been identified. The results of the study contribute to the development of methods for assessing the sustainable development of a region.
\end{abstract}

Key words: region, methods, sustainability factors, assessment of the territory's potential, level of sustainability, Southern Federal District, North Caucasus Federal District.

Citation. Arzumanyan M.S. Methodological Tools for Assessing the Level of Stability of the Regions of the Southern and North Caucasus Federal Districts of Russia. Journal of Volgograd State University. Economics, 2020, vol. 22, no. 2, pp. 75-85. (in Russian). DOI: https://doi.org/10.15688/ek.jvolsu.2020.2.7

УДК 332.1

ББК 65.049(2)
Дата поступления статьи: 02.03.2020

Дата принятия статьи: 20.04.2020

\section{МЕТОДИЧЕСКИЙ ИНСТРУМЕНТАРИЙ ОЦЕНКИ У РОВНЯ УСТОЙЧИВОСТИ РЕГИОНОВ ЮЖНОГО И СЕВЕРО-КАВКАЗСКОГО ФЕДЕРАЛЬНЫХ ОКРУГОВ РОССИИ}

\footnotetext{
Мисак Спартакович Арзуманян

Красноярский государственный аграрный университет, г. Красноярск, Российская Федерация

Аннотация. Благодаря основным политическим документам, принятым на Всемирном саммите ООН по окружающей среде и развитию в Рио-де-Жанейро в 1992 г. произошла активизация формирования системы устойчивого развития в России. В Российской Федерации продолжается переход к устойчивому развитию посредством логической трансформации традиционных систем в капиталистические. Ввиду многообразия различий в социально-экономическом развитии регионов, дифференцированных по федеральным округам, становится актуальной разработка методик определения (оценки) уровней устойчивости террито-
} 
риальных образований. Многими исследователями критерии (показатели) устойчивости, как правило, группируются в разрезе экономической, социальной и экологической компонент. Цель статьи - определение уровня устойчивости регионов Южного и Северо-Кавказского федеральных округов России посредством количественной оценки их потенциалов. В статье на основе математических методов количественно определены составные компоненты устойчивости (потенциала) регионов по пяти факторам устойчивости: экономическому, политическому, экологическому, социальному и институциональному. Установлены критерии для выделения уровней устойчивости регионов. Выявлены наиболее устойчивые регионы (субъекты) Южного и Северо-Кавказского федеральных округов России - Ростовская и Волгоградская области, Краснодарский и Ставропольский края. Результаты исследования вносят вклад в развитие методического инструментария оценки устойчивого развития региона.

Ключевые слова: регион, методы, факторы устойчивости, оценка потенциала территории, уровень устойчивости, Южный федеральный округ, Северо-Кавказский федеральный округ.

Цитирование. Арзуманян М. С. Методический инструментарий оценки уровня устойчивости регионов Южного и Северо-Кавказского федеральных округов России // Вестник Волгоградского государственного университета. Экономика. - 2020. - Т. 22, № 2. - C. 75-85. - DOI: https://doi.org/10.15688/ek.jvolsu.2020.2.7

\section{Введение}

Южная часть России, представленная Южным и Северо-Кавказским федеральными округами, является одной из климатически привлекательных территорий страны с нестабильным социально-экономическим положением, обусловленным этническими и конфессиональными различиями.

Южный федеральный округ (далее ЮФО) образован Указом Президента РФ от 13 мая 2000 г. [Указ Президента РФ от 13.05.2000 № 849]; имеет в своем составе (после выделения из него Северо-Кавказского и включения Крымского федерального округа) восемь субъектов РФ с населением более 16 млн чел. (11\% от населения РФ), среди которых: три республики (Адыгея, Калмыкия, Крым), три области (Астраханская, Волгоградская, Ростовская), один край (Краснодарский) и один город федерального значения (г. Севастополь). Территория округа составляет $2,5 \%$ (сороковую часть) от территории РФ. Административным центром и одним из двух городов-миллионеров округа является Ростов-на-Дону. В 2010 г. из его состава выделен Северо-Кавказский федеральный округ (далее - СКФО) с центром в городе Пятигорске.

СКФО состоит из семи субъектов РФ (1 край - Ставропольский и шесть республик - Дагестан, Ингушетия, Кабардино-Балкарская, Карачаево-Черкесская, Северная Осетия (Алания) и Чеченская) с населением почти 10 млн чел.; занимает около 1 \% территории России. Доля сельского хозяйства в от- раслевой структуре валового продукта округа составляет $16,4 \%$, причем основную часть $(57,3 \%)$ занимает продукция растениеводства. В целях устойчивого развития отрасли, помимо государственной финансовой поддержки, проведения модернизации, внедрения современных технологий в производство, необходимы мероприятия по повышению уровня финансовой устойчивости крупных и средних организаций [Мещерякова, 2020, с. 48-49].

В общих положениях Стратегии социально-экономического развития ЮФО (на период до 2020 г.) и СКФО (на период до 2025 г.) определены ее цели - постоянное повышение уровня и качества жизни населения, а также устойчивое развитие экономики [Распоряжение Правительства РФ от 05.09.2011 № 1538-p]; достижение устойчивого развития и обеспечение национальной безопасности Российской Федерации [Распоряжение Правительства РФ от 06.09.2010 № 1485-p].

Благодаря основным политическим документам, принятым на Всемирном саммите ООН по окружающей среде и развитию в Рио-де-Жанейро в 1992 г., произошла активизация концепции устойчивого развития в России. Целью перехода нашей страны к устойчивому развитию является формирование такого общества, которое будет развиваться согласно принципам коэволюции общества и природы, будет жить не только ради себя, но и во благо будущих поколений [Сабрекова, 2020, c. 172].

В Концепции перехода Российской Федерации к устойчивому развитию установлено, 
что необходимо реализовать в Российской Федерации логическую трансформацию, гарантирующую сбережение окружающей среды и естественно-ресурсных возможностей для удовлетворения нужд современного и последующих поколений людей [Ачох, 2020, с. 61].

Следовательно, в экономических дискуссиях ставится вопрос о формировании новой модели социально-экономического развития. Структурные преобразования на современном этапе развития экономики России рассматриваются как фундамент модернизации экономики в направлении формирования новой модели социально-экономического развития. Формирование новой структуры экономики, способной обеспечивать нефрагментарное благополучие отождествляется с понятием «новая индустриализация» [Байбулатова, 2020, с. 29].

Выделяют следующие принципы концепции «устойчивого развития»: долгосрочная ориентация, системный подход, эффективное использование, ресурсов, вовлеченность [Мороз и др., 2020, с. 62].

Наряду с концепцией устойчивого развития в последние два десятилетия развивается концепция зеленой экономики, которая в отличие от первой делает акцент на экономический рост, не противоречащий стратегиям снижения опасных воздействий на окружающую среду [Зомонова, 2016, с. 15].

Критерии (показатели) устойчивости, как правило, группируются в разрезе экономической, социальной и экологической компонент. Экономическая составляющая ассоциируется с оптимальным использованием ресурсов, обеспечением финансовой независимости и устойчивости, инновационной активности, конкурентоспособности продукции или услуг. Социальные стороны - факторы развития коллектива (безопасность труда, стабильная заработная плата, дополнительное медицинское и социальное страхование работников, повышение квалификации, участие в социальных мероприятиях, разработанных для поддержания социального благополучия, безопасности и стабильности работников. Экологическая устойчивость компании определяется ее деятельностью по охране и восстановлению окружающей среды, включая уменьшение вредных выбросов [Аблякимова, 2020, с. 50].

\section{Методы исследования}

Ученые-исследователи связывают устойчивое развитие с качеством (эффективностью) жизни населения, в частности, с индексом человеческого развития. Вводились индикаторы устойчивого развития, разрабатывались методы стандартизации (система индикаторов устойчивого развития, предложенная Комиссией $\mathrm{OOH} \mathrm{по} \mathrm{устойчивому} \mathrm{развитию} \mathrm{(КУР));} \mathrm{сис-}$ тема интегрированных экологических и экономических национальных счетов (A System for Integrated Environmental and Economic Accounting), предложенная Статистическим отделом ООН; индикаторы мирового развития Всемирного Банка; программа экологических индикаторов ОЭСР; система индикаторов для улучшения управления природопользованием в Центральной Америке; система эколого-экономического учета (СЭЭУ) была предложена Статистическим отделом Секретариата $\mathrm{OOH}$ в 1993 г.; показатель «истинных сбережений» (genuine savings), разработанный и рассчитанный Всемирным Банком; индекс развития человеческого потенциала (ИРЧП); индекс «живой планеты» (ИЖП) (Living Planet Index) для оценки состояния природных экосистем планеты исчисляется в рамках ежегодного доклада Всемирного Фонда Дикой Природы (World Wild Fund); индекс реального прогресса и индекс устойчивого экономического благосостояния (Genuine Progress Indicators и Index of Sustainable Economic Welfare) [Аванесов, 2014, c. 16].

Белорусские ученые предлагают при исследовании качества жизни в качестве методов опираться на унифицированные характеристики, позволяющие на основе анализа определять рейтинг регионов и учитывающие все основные элементы, обеспечивающие устойчивое развитие: благосостояние, социальная безопасность (или качество социальной сферы), качество населения (способность к воспроизводству), условия жизни населения, информированность населения, качество окружающей среды, природно-климатические условия [Белорусова, 2018, с. 10].

Учеными [Методический подход ... , 2018, с. 656-657] предлагается методика комплексной оценки устойчивого развития региона в условиях экологизации экономики. В основе нее лежат межрегиональные сравнения, 
осуществляемые с целью выявления лучшего значения (эталона) по каждому фактору с дальнейшей стандартизацией остальных значений. Стандартизированные значения находятся в диапазоне [0; 1], что по математическим соображениям вполне обоснованно. Далее рассчитывается интегральный индекс по формуле средней арифметической от трех локальных индексов (экономического, социального, экологического), что в данной ситуации уступает по обоснованности применению средней геометрической (с предварительным увеличением значения каждого индекса на единицу). Также вводится значение интегрального индекса в 0,75 (без обоснования), интерпретируемое в качестве границы между «достаточно высоким уровнем развития» и «существенно отстающим от наилучшего достигнутого уровня». На третьем этапе методики строится «Матрица комплексной оценки устойчивого развития региона» с выделением четырех уровней развития (квадрантов с «длиной» в 0,25$)$. Несложно понять, что, если значение 1 изначально задавалось как «идеальное», а плоскость делится на четыре равные части, каждая из них принимает значение в 0,25 . При этом в статье отсутствует наглядность расчетов на каждом из этапов методики.

Автор настоящей статьи, проанализировав положительные идеи и подходы других ученых по схожей проблематике и учтя недостатки иных методик по оценке уровня устойчивости регионов, предлагает свое видение таковой. Применяются методы, являющиеся авторскими: «приращение единицы» и «эталонно-пропорциональный». Они позволяют осуществить количественную оценку устойчивости регионов Южного и Северо-Кавказского федеральных округов России на основе анализа их потенциала по факторам устойчивости: экономическому, политическому, экологическому, социальному и институциональному.

Согласно методу «приращение единицы» преобразованные значения показателей увеличиваются на единицу, которая играет роль «фундамента» или «основы» для каждого преобразованного значения показателя; все дополнительные «преимущества» значений показателей в сравнении между собой - вносят линейно-корректирующий вклад в их конечные значения. В результате перемножения не- скольких значений различных показателей их интегрированное значение, выражаясь языком начисления процентов, «капитализируется».

Метод «эталонно-пропорциональный» из преобразованных значений каждого показателя выделяет наименьшее значение (в разрезе регионов), придавая им статус «эталонов» со значением 1 . По каждому показателю все значения необходимо поделить на значение соответствующего «эталона».

Каждый фактор устойчивости представлен входящими в него составляющими элементами и отражает их сущность; общее число элементов - семь $(s, a, g, p, e, c, d)$, которые в свою очередь состоят суммарно из 19 показателей. Каждый из элементов предполагается оценивать по 2-3 показателям. Использование методов направлено на расчет интегрированных значений по территориальным образованиям (регионам).

Методика включает в себя процедуру установления критериев для выделения уровней устойчивости регионов (субъектов) РФ.

\section{Результаты исследования}

Определяются исходные (абсолютные) значения показателей, количественно отражающих различные составляющие устойчивого развития регионов Южного и Северо-Кавказского федеральных округов. Значения показателей даны в разрезе элементов, которые в свою очередь объединены в составе факторов устойчивости.

Показатели с 1.1 по 7.3 представлены ниже [в скобках указаны их значения по каждому из регионов Южного и Северо-Кавказского федеральных округов (регионы соответствуют представленным в таблице 1)].

\section{I. Экономический фактор:}

1. Близость к высокоразвитым территориям $(s)$ :

1.1. Затраты на технологические инновации (2018 г.), млрд руб. / год $(0,34 ; 0,02 ; 0,60$; 11,$58 ; 1,79 ; 7,13 ; 19,59 ; 0,08 ; 0,67 ; 0,00 ; 0,33 ; 0,01$; 0,04; 0,01; 6,08) [Регионы России ... , с. 1029].

1.2. Уровень доходов на душу населения (2019 г.), руб. / мес. (33 903; 23 270; 24 441; 40 380; 28 642; 29 087; 37 064; 34 285; 35 150; 21 602; 26 095; 22 363; 29 321; 29 119; 29 014) [Среднедушевые денежные доходы населения]. 
2. Возможность ведения сельского хозяйства, потенциал для промышленного производства $(a)$ :

2.1. Уровень плодородия почвы (2018 г.), ц зерна с га посевной площади $(38,4 ; 22,9 ; 15,0$; 52,$9 ; 27,1 ; 19,3 ; 31,9 ; 19,3 ; 25,3 ; 23,0 ; 54,1 ; 46,4$; $55,4 ; 24,7 ; 36,6)$ [Регионы России ... , с. 755].

2.2. Уровень развития промышленности (обрабатывающие производства) (2018 г.), млрд руб. $(52,5 ; 0,9 ; 93,5 ; 1025,1 ; 61,9 ; 882,6$; $906,8 ; 11,3 ; 45,6 ; 2,1 ; 30,9 ; 31,2 ; 19,4 ; 10,4 ; 298,6)$ [Регионы России ..., с. 655].

2.3. Наличие высококвалифицированных кадров (2018 г.), тыс. чел. $(3,4 ; 1,7 ; 10,0 ; 25,2$; 6,$0 ; 13,5 ; 31,6 ; 2,8 ; 13,2 ; 1,6 ; 3,1 ; 2,1 ; 5,1 ; 6,1$; 15,2) [Регионы России ..., с. 367].

\section{II. Политический фактор:}

3. Географическое положение региона Южного / Северо-Кавказского федерального округа $(g)$ :

3.1. Удаленность центра региона от центра округа, км (331; 452; 715; 274; 772; 470; 0 ; $802 ; 442 ; 198 ; 85 ; 105 ; 199 ; 294 ; 200)$ [Расчет расстояний ...].

3.2. Добыча полезных ископаемых (2018 г.), млрд руб. (3,4; 0; 14,4; 52,5; 346,0; 63,5; $33,5 ; 0 ; 5,4 ; 1,1 ; 0,2 ; 2,8 ; 0,7 ; 5,3 ; 10,5)$ [Регионы России ..., с. 653-654].

3.3. Благоприятность природно-климатических условий (средняя месячная температура воздуха в июле) $\left(2018\right.$ г.), ${ }^{\circ} \mathrm{C}(24,3 ; 27,2$; 23,$5 ; 24,8 ; 27,9 ; 25,3 ; 25,4 ; 23,5 ; 24,0 ; 23,4 ; 26,0$; $19,1 ; 24,9 ; 25,7 ; 23,5)$ [Окружающая среда ...].

4. Политическое расположение региона Южного / Северо-Кавказского федерального округа $(p)$ :

4.1. Стратегическая значимость территории (величина валового регионального продукта) (2017 г.), млрд руб. (99; 67; 359; 2 226; 421; 771; $1347 ; 71 ; 623 ; 56 ; 138 ; 75 ; 128 ; 179$; 665) [Регионы России ..., с. 476].

4.2. Этническая лояльность (2017 г.), \% $(77,5 ; 86,1 ; 82,2 ; 83,8 ; 78,7 ; 76,8 ; 74,0 ; 79,5 ; 71,5$; $91,6 ; 84,6 ; 79,2 ; 69,2 ; 89,9 ; 70,1)$ [Доля граждан, положительно оценивающих состояние межнациональных отношений].

4.3. Конфессиональная лояльность (2017 г.), \% (77,5; 87,7; 80,0; 81,6; 78,3; 76,8; 75,5; 79,$5 ; 65,9 ; 91,5 ; 78,8 ; 80,9 ; 73,7 ; 89,1 ; 71,6$ ) [Доля граждан, положительно оценивающих состояние межконфессиональных отношений].

\section{III. Экологический фактор:}

5. Экологическая обстановка в регионе Южного / Северо-Кавказского федеральных округов (e):

5.1. Затраты на охрану окружающей среды (2018 г.), млн руб. (449; 238; 3 146; 12 095; 3 958; 8 866; 6 544; 607; 476; 55; 455; 488; 625; 1 092; 4 984) [Регионы России ..., с. 471].

5.2. Загрязненность территории (2018 г.), тыс. т $(8 ; 4 ; 23 ; 825 ; 33 ; 145 ; 57 ; 3 ; 14 ; 1 ; 3 ; 15$; 11; 14; 95) [Регионы России ... , с. 457].

\section{IV. Социальный фактор:}

6. Развитие социальной сферы в регионе Южного / Северо-Кавказского федерального округа (c):

6.1. Образование (обеспеченность детей дошкольного возраста местами в организациях, осуществляющих образовательную деятельность, присмотр и уход за детьми) (2018 г.), \% от численности детей $(49,5$; 68,$3 ; 52,2 ; 58,2 ; 64,4 ; 63,6 ; 58,1 ; 51,7 ; 25,3$; $29,6 ; 65,3 ; 53,2 ; 47,6 ; 31,1 ; 58,3)$ [Регионы России ..., с. 302].

6.2. Здравоохранение (численность населения на одну больничную койку) (2018 г.), чел. $(132,9 ; 127,7 ; 131,1 ; 136,1 ; 112,9 ; 114,0 ; 124,5$; 124,$8 ; 143,8 ; 225,5 ; 133,1 ; 145,6 ; 112,6 ; 171,7$; 119,5) [Регионы России ..., с. 379].

6.3. Социальная защита населения (число учреждений социальной помощи для лиц без определенных места жительства и занятий) (2017 г.), ед. $(0 ; 1 ; 1 ; 5 ; 1 ; 2 ; 6 ; 1 ; 1 ; 0 ; 0 ; 0 ; 1 ; 0 ; 1)$ [Число учреждений ...].

\section{V. Институциональный фактор:}

7. Уровень развития демократии в регионе Южного / Северо-Кавказского федерального округа $(d)$ :

7.1. Численность работников в местных администрациях (исполнительно-распорядительных органах муниципальных образований) (2018 г.), чел. (1 724; 1 362; 5 630; 12 882; 3 374; 8 701; 17 056; 186; 7 389; 661; 2 647; 2 183; 1 626; 3 923; 9 662) [Регионы России ... , с. 187].

7.2. Доверие к власти, \% голосовавших за президента В.В. Путина на выборах в 2018 г. $(81,17 ; 81,66 ; 92,15 ; 81,35 ; 76,95 ; 77,55 ; 78,97$; 90,19; 90,76; 83,17; 93,38; 87,64; 81,51; 91,44; 80,55) [Федеральные выборы: процент ...].

7.3. Политический интерес к жизни страны, явка избирателей на выборы президента в 2018 г., \% (74,31; 69,45; 71,55; 77,87; 60,42; 
68,14; 64,77; 71,44; 87,48; 81,96; 91,8; 87,41;89,99; 91,54; 73,85) [Федеральные выборы: явка ...].

Затем осуществляется преобразование значений показателей в «позитивный» вид, то есть чем выше их значение, тем это благоприятнее для региона. Оптимальные варианты перевода значений - на основе критериев: доля в структуре (доля значения $n$-го показателя в сумме значений $n$-го показателя), удаленность от наибольшего значения, доля от единицы, близость к среднему значению.

Показатели с 1.1 до 7.3 представлены ниже (в скобках указаны их преобразованные значения по каждому из регионов Южного и Северо-Кавказского федеральных округов).

\section{I. Экономический фактор:}

1. Близость к высокоразвитым территориям $(s)$ :

1.1. Затраты организаций на технологические инновации, доля в структуре $(0,01 ; 0 ; 0,01$; $0,24 ; 0,04 ; 0,15 ; 0,41 ; 0 ; 0,01 ; 0 ; 0 ; 0 ; 0 ; 0 ; 0,13)$;

1.2. Уровень доходов на душу населения, доля в структуре $(0,08 ; 0,05 ; 0,05 ; 0,09$; 0,$06 ; 0,07 ; 0,08 ; 0,08 ; 0,08 ; 0,05 ; 0,06 ; 0,05 ; 0,07$; 0,$07 ; 0,06$ ).

2. Возможность ведения сельского хозяйства или потенциал для промышленного производства $(a)$ :

2.1. Уровень плодородия почвы, доля в структуре $(0,08 ; 0,05 ; 0,03 ; 0,11 ; 0,06 ; 0,04 ; 0,06$; $0,04 ; 0,05 ; 0,05 ; 0,11 ; 0,09 ; 0,11 ; 0,05 ; 0,07)$.

2.2. Уровень развития промышленности, доля в структуре $(0,02 ; 0 ; 0,03 ; 0,29 ; 0,02 ; 0,25$; $0,26 ; 0 ; 0,01 ; 0 ; 0,01 ; 0,01 ; 0,01 ; 0 ; 0,09)$.

2.3. Наличие высококвалифицированных кадров, доля в структуре $(0,02 ; 0,01 ; 0,07 ; 0,18$; 0,$04 ; 0,1 ; 0,23 ; 0,02 ; 0,09 ; 0,01 ; 0,02 ; 0,02 ; 0,04$; 0,$04 ; 0,11$ ).

\section{II. Политический фактор:}

3. Географическое положение региона Южного / Северо-Кавказского федерального округа $(g)$ :

3.1. Близость центра региона к центру округа, удаленность от наибольшего значения $(0,59 ; 0,44 ; 0,11 ; 0,66 ; 0,04 ; 0,41 ; 1,00 ; 0 ; 0 ; 0,55$; $0,81 ; 0,76 ; 0,55 ; 0,33 ; 0,55)$.

3.2. Добыча полезных ископаемых, доля в структуре $(0,01 ; 0 ; 0,03 ; 0,10 ; 0,64 ; 0,12 ; 0,06$; $0 ; 0,01 ; 0 ; 0 ; 0 ; 0 ; 0,01 ; 0,02)$.

3.3. Благоприятность природно-климатических условий, доля в структуре $(0,07 ; 0,07$;
0,$06 ; 0,07 ; 0,08 ; 0,07 ; 0,07 ; 0,06 ; 0,07 ; 0,06 ; 0,07$; $0,05 ; 0,07 ; 0,07 ; 0,06)$.

4. Политическое расположение региона Южного / Северо-Кавказского федерального округа $(p)$ :

4.1. Стратегическая значимость территории (величина валового регионального продукта), доля в структуре $(0,01 ; 0,01 ; 0,05 ; 0,31$; 0,$06 ; 0,11 ; 0,19 ; 0,01 ; 0,08 ; 0,01 ; 0,02 ; 0,01 ; 0,02$; $0,02 ; 0,09)$.

4.2. Этническая лояльность, доля от единицы $(0,775 ; 0,861 ; 0,822 ; 0,838 ; 0,787 ; 0,768$; 0,$740 ; 0,795 ; 0,715 ; 0,916 ; 0,846 ; 0,792 ; 0,692$; $0,899 ; 0,701)$.

4.3. Конфессиональная лояльность, доля от единицы $(0,775 ; 0,877 ; 0,800 ; 0,816 ; 0,783$; 0,$768 ; 0,755 ; 0,795 ; 0,659 ; 0,915 ; 0,788 ; 0,809$; $0,737 ; 0,891 ; 0,716)$.

\section{III. Экологический фактор:}

5. Экологическая обстановка в регионе Южного / Северо-Кавказского федерального округа (e):

5.1. Затраты на охрану окружающей среды, доля в структуре $(0,01 ; 0,01 ; 0,07 ; 0,28$; 0,$09 ; 0,20 ; 0,15 ; 0,01 ; 0,01 ; 0 ; 0,01 ; 0,01 ; 0,01$; $0,03 ; 0,11)$.

5.2. Чистота территории, удаленность от наибольшего значения $(0,99 ; 1,00 ; 0,97 ; 0$; 0,$96 ; 0,82 ; 0,93 ; 1,00 ; 0,98 ; 1,00 ; 1,00 ; 0,98$; $0,99 ; 0,98 ; 0,88)$.

\section{IV. Социальный фактор:}

6. Развитие социальной сферы в регионе Южного / Северо-Кавказского федерального округа $(c)$ :

6.1. Образование (обеспеченность детей дошкольного возраста местами в организациях, осуществляющих образовательную деятельность, присмотр и уход за детьми), доля от общей численности детей $(0,495 ; 0,683$; 0,$522 ; 0,582 ; 0,644 ; 0,636 ; 0,581 ; 0,517 ; 0,253$; $0,296 ; 0,653 ; 0,532 ; 0,476 ; 0,311 ; 0,583)$.

6.2. Здравоохранение (численность населения на одну больничную койку), удаленность от наибольшего значения $(0,41 ; 0,43 ; 0,42 ; 0,40$; 0,$50 ; 0,49 ; 0,45 ; 0,45 ; 0,36 ; 0 ; 0,41 ; 0,35 ; 0,50$; $0,24 ; 0,47)$.

6.3. Социальная защита населения (число учреждений социальной помощи для лиц без определенных места жительства и занятий), доля в структуре $(0 ; 0,05 ; 0,05 ; 0,25 ; 0,05 ; 0,10$; $0,30 ; 0,05 ; 0,05 ; 0 ; 0 ; 0 ; 0,05 ; 0 ; 0,05)$. 
V. Институциональный фактор:

7. Уровень развития демократии в регионе Южного / Северо-Кавказского федерального округа $(d)$ :

7.1. Численность муниципальных служащих в органах местного самоуправления на 10 тыс. чел. постоянного населения, чел.: 37,$89 ; 50,07 ; 29,45 ; 22,81 ; 33,27 ; 34,69 ; 40,58$; 4,20;23,94; 13,27; 30,57; 46,85; 23,26; 26,93; 34,57 [Регионы России ..., с. 43]; близость к среднему значению $(0,74 ; 0,34 ; 0,98 ; 0,76 ; 0,90 ; 0,85$; $0,65 ; 0,14 ; 0,79 ; 0,44 ; 0,99 ; 0,45 ; 0,77 ; 0,89 ; 0,85)$;

7.2. Доверие к власти, доля в структуре $(0,8117 ; 0,8166 ; 0,9215 ; 0,8135 ; 0,7695 ; 0,7755$; 0,$7897 ; 0,9019 ; 0,9076 ; 0,8317 ; 0,9338 ; 0,8764$; $0,8151 ; 0,9144 ; 0,8055)$;

7.3. Политический интерес к жизни страны, доля от единицы $(0,7431 ; 0,6945 ; 0,7155$; 0,$7787 ; 0,6042 ; 0,6814 ; 0,6477 ; 0,7144 ; 0,8748$; $0,8196 ; 0,9180 ; 0,8741 ; 0,8999 ; 0,9154 ; 0,7385)$.

Для регионов Южного и Северо-Кавказского федеральных округов значение каждого элемента - среднее значение из преобразованных значений показателей, входящих в состав элемента. Порядок образования интегрированных значений по методам «приращение единицы» и «эталонно-пропорциональный» для каждого региона такой же, как и для средних геометрических - формируются в результате произведения семи преобразованных зна- чений элементов с извлечением корня седьмого порядка (табл. 1).

Введем обозначения: интегрированные значения регионов Южного и Северо-Кавказского федеральных округов России, полученные по методу «приращение единицы» $-\sqrt[n]{R}$; полученные по «эталонно-пропорциональному» методу $-\sqrt[n]{F}$; агрегированные значения регионов $-\sqrt{T * K}$. Таким образом, имеет место трансформация: $I_{1} \rightarrow T ; I_{2} \rightarrow K ; A \rightarrow Z$.

Прогноз интегрированных значений показателей по методу «приращение единицы» не вызывает сложностей, ввиду логичности и простоты его использования. Поскольку максимальное значение $R$ ограничено снизу значением 1 , а сверху - значением 2 , то и значение $T=\sqrt[n]{\mathrm{R}}$, где $n$ - число элементов (в нашем случае оно равно семи, по числу элементов) будет также в интервале $[1 ; 2]$. Здесь можно ввести «квадранты» аналогично тем, что в работе [Методический подход ... , 2018, с. 657], с выделением четырех интервалов: $[1,00 ; 1,25]$, $[1,26 ; 1,50],[1,51 ; 1,75]$ и $[1,76 ; 2]$, с характеристиками: слабый, умеренный, средний и высокий уровни устойчивости. В то же время метод «приращение единицы» формирует заниженные значения, особенно по тем показателям, преобразованные значения по которым определяются на основе доли значений $n$-го показателя в сумме значений $n$-го показателя.

Таблииа 1

Интегрированные значения элементов факторов устойчивости регионов Юга России

\begin{tabular}{|c|c|c|c|c|c|c|c|c|}
\hline \multirow{2}{*}{$\begin{array}{c}\text { № } \\
\Pi / \Pi\end{array}$} & \multirow{2}{*}{ Регионы / субъекты } & \multicolumn{7}{|c|}{ Значения элементов } \\
\hline & & $S$ & $a$ & $g$ & $p$ & $e$ & $c$ & $d$ \\
\hline \multicolumn{9}{|c|}{ Южный федеральный округ } \\
\hline 1 & Республика Адыгея & 0,04 & 0,04 & 0,22 & 0,52 & 0,50 & 0,30 & 0,76 \\
\hline 2 & Республика Калмыкия & 0,03 & 0,02 & 0,17 & 0,58 & 0,51 & 0,39 & 0,62 \\
\hline 3 & Республика Крым & 0,03 & 0,05 & 0,07 & 0,56 & 0,52 & 0,33 & 0,87 \\
\hline 4 & Краснодарский край & 0,16 & 0,19 & 0,28 & 0,65 & 0,14 & 0,41 & 0,78 \\
\hline 5 & Астраханская область & 0,05 & 0,04 & 0,25 & 0,54 & 0,53 & 0,40 & 0,76 \\
\hline 6 & Волгоградская область & 0,11 & 0,13 & 0,20 & 0,55 & 0,51 & 0,41 & 0,77 \\
\hline 7 & Ростовская область & 0,24 & 0,18 & 0,38 & 0,56 & 0,54 & 0,44 & 0,70 \\
\hline 8 & Город федерального значения Севастополь & 0,04 & 0,02 & 0,02 & 0,53 & 0,51 & 0,34 & 0,59 \\
\hline \multicolumn{9}{|c|}{ Северо-Кавказский федеральный округ } \\
\hline 9 & Республика Дагестан & 0,04 & 0,05 & 0,03 & 0,48 & 0,50 & 0,22 & 0,86 \\
\hline 10 & Республика Ингушетия & 0,03 & 0,02 & 0,20 & 0,61 & 0,50 & 0,10 & 0,70 \\
\hline 11 & Кабардино-Балкарская Республика & 0,03 & 0,05 & 0,29 & 0,55 & 0,51 & 0,35 & 0,95 \\
\hline 12 & Карачаево-Черкесская Республика & 0,03 & 0,04 & 0,27 & 0,54 & 0,50 & 0,29 & 0,73 \\
\hline 13 & Республика Северная Осетия - Алания & 0,04 & 0,05 & 0,21 & 0,48 & 0,50 & 0,34 & 0,83 \\
\hline 14 & Чеченская Республика & 0,04 & 0,03 & 0,14 & 0,60 & 0,51 & 0,18 & 0,91 \\
\hline 15 & С тавропольский край & 0,09 & 0,09 & 0,21 & 0,50 & 0,50 & 0,37 & 0,80 \\
\hline
\end{tabular}


Но особую трудность вызывает интерпретация агрегированных значений, вызванная неопределенностью верхнего предела значений показателей по «эталонно-пропорциональному» методу, механизму определения локального доминирования значений показателей, не ограниченных «сверху», то есть могущих принять какое угодно значение. Нормативное значение при этом отсутствует. Достоверно известно лишь то, что минимальное («эталонное») значение $F$ равно 1.

Комплексное применение обоих методов стабилизирует (сглаживает) общую ситуацию, компенсирует частные недостатки обеих методов. Поэтому наиболее рациональным решением является оценка потенциала регионов по агрегированным значениям, сочетающим в себе эффект обоих методов.

На основе расчетов определено, что агрегированные значения показателей некоторых регионов (с абсолютным уровнем устойчивости) превосходят верхний предел по методу «приращение единицы», равный двум, что объясняется неравномерным распределением «потенциала» среди территориальных образований. Но в остальных случаях эти значения в рамках интервала $[1 ; 2]$.

В связи с вышеизложенными аргументами интерпретацию расчетных значений $Z$ (определение уровня устойчивости региона) автор предлагает осуществлять на основе следующей шкалы: слабый $(<1,25)$; умеренный $(1,26-1,50)$; средний $(1,51-1,75)$; высокий $(1,76-2,00)$; абсолютный $(>2,00)$. Результаты представлены в таблице 2 .

Из 15 субъектов ЮФО и СКФО уровень устойчивости определен следующий: абсолютный - у четверых; высокий - у пяти; средний - у пяти; умеренный - у одного.

Из указанных выше регионов лучший уровень устойчивости - у Ростовской области; далее по рейтингу идут - Волгоградская область, Краснодарский и Ставропольский края.

\section{Заключение}

В статье предложена методика количественной оценки и определения уровня устойчивости регионов Южного и Северо-Кавказского федеральных округов России на основе анализа их потенциала по пяти факторам устойчивости. Определены наиболее устойчивые регионы (субъекты) Южного и Северо-Кавказского федеральных округов России (Ростовская и Волгоградская области, Краснодарский и Ставропольский края).

Областью практического применения данного методического инструментария оценки уровня устойчивости территориальных образований является региональная социальноэкономическая система, интегрированная в национальное пространство. «Эталонно-про-

Уровень устойчивости регионов ЮФО и СКФО

Таблица 2

\begin{tabular}{|c|c|c|c|c|c|}
\hline $\begin{array}{l}№ \\
\Pi / \Pi\end{array}$ & Регионы / субъекты & $T$ & $K$ & $Z$ & $\begin{array}{c}\text { Уровень } \\
\text { устойчивости }\end{array}$ \\
\hline \multicolumn{6}{|c|}{ Южный федеральный округ } \\
\hline 1 & Республика Адыгея & 1,3173 & 2,3847 & 1,77 & высокий \\
\hline 2 & Республика Калмыкия & 1,3095 & 2,0523 & 1,64 & средний \\
\hline 3 & Республика Крым & 1,3157 & 2,1072 & 1,67 & средний \\
\hline 4 & Краснодарский край & 1,3540 & 3,3957 & 2,14 & абсолютный \\
\hline 5 & Астраханская область & 1,3441 & 2,6486 & 1,89 & высокий \\
\hline 6 & Волгоградская область & 1,3642 & 3,4065 & 2,16 & абсолютный \\
\hline 7 & Ростовская область & 1,4240 & 4,4041 & 2,50 & абсолютный \\
\hline 8 & Город федерального значения Севастополь & 1,2699 & 1,5140 & 1,39 & умеренный \\
\hline \multicolumn{6}{|c|}{ Северо-Кавказский федеральный округ } \\
\hline 9 & Республика Дагестан & 1,2812 & 1,7829 & 1,51 & средний \\
\hline 10 & Республика Ингушетия & 1,2821 & 1,7673 & 1,51 & средний \\
\hline 11 & Кабардино-Балкарская республика & 1,3598 & 2,6223 & 1,89 & Высокий \\
\hline 12 & Карачаево-Черкесская республика & 1,3208 & 2,3444 & 1,76 & высокий \\
\hline 13 & Республика Северная Осетия - Алания & 1,3256 & 2,4926 & 1,82 & высокий \\
\hline 14 & Чеченская республика & 1,3108 & 2,0948 & 1,66 & средний \\
\hline 15 & Ставропольский край & 1,3453 & 3,0827 & 2,04 & абсолютный \\
\hline
\end{tabular}


порциональный» метод позволяет количественно диагностировать уровень дифференциации регионов по экономическому, политическому, экологическому, социальному и институциональному факторам устойчивого развития. Методика предназначена для исследователей проблем регионального развития, регулирования пространственного социальноэкономического развития на межрегиональном, региональном и муниципальном уровнях, органов исполнительной власти субъектов Российской Федерации, а также органов муниципального уровня власти (местного самоуправления) для выявления наиболее и наименее устойчивых территориальных образований. Результаты будущего анализа послужат достоверной информацией в принятии управленческих решений регионального (муниципального) уровня, реализации региональной экономической политики, в частности, обоснования пропорций в объеме финансирования, направляемого на развитие конкретных территорий.

\section{СПИСОК ЛИТЕРАТУРЫ}

Аблякимова, Л. Р. Критерии оценки устойчивого развития / Л. Р. Аблякимова // Экономика в теории и на практике: актуальные вопросы и современные аспекты : сб. ст. III Междунар. науч.-практ. конф. (г. Пенза, 25 января 2020 г.). - Пенза : [б. и.], 2020.-С. 49-51.

Аванесов, Е. К. Качество жизни и стандартизация индикаторов устойчивого развития / Е. К. Аванесов // Экономика качества. - 2014. - № 1 (5). C. $11-22$.

Ачох, Ю. Р. Устойчивое развитие природно-экономических систем / Ю. Р. Ачох // Инновационная траектория развития современной науки: становление, развитие, прогнозы : сб. ст. Междунар. науч.-практ. конф. (г. Петрозаводск, 2 февраля 2020 г.). - Петрозаводск : Новая наука, 2020.- С. 59-63.

Байбулатова, Р. 3. Устойчивое развитие в условиях новой индустриализации экономики / Р. 3. Байбулатова // Инновационное развитие науки и образования : сб. ст. IX Междунар. науч.-практ. конф. : в 2 ч. (г. Пенза, 12 января 2020 г.). Пенза : [б. и.], 2020. - С. 29-33.

Белорусова, Н. Л. Качество жизни как фактор устойчивого развития региона / Н. Л. Белорусова // Экономика. Бизнес. Финансы. - 2018. № 11. - C. 9-13.
Доля граждан, положительно оценивающих состояние межконфессиональных отношений. Электрон. текстовые дан. - Режим доступа: https://www.fedstat.ru/indicator/50995 (дата обращения: 10.03.2020). - Загл. с экрана.

Доля граждан, положительно оценивающих состояние межнациональных отношений. - Электрон. текстовые дан. - Режим доступа: https:// www.fedstat.ru/indicator/50996 (дата обращения: 10.03.2020). - Загл. с экрана.

Зомонова, Э. М. Понятия и принципы «зеленой» экономики / Э. М. Зомонова. - Улан-Удэ : Экономические науки, 2016. - С. 13-17.

Методический подход к комплексной оценке устойчивого развития региона в условиях экологизации экономики / Е. А. Третьякова [и др.] // Вестник УрФУ. Серия: Экономика и управление. - 2018. - Т. 17, № 4. - С. 651-669.

Мещерякова, Ж. В. Пространственно-динамические модели прогнозирования устойчивого развития сельского хозяйства региона / Ж. В. Мещерякова // Лучшая научно-исследовательская работа 2020 : сб. ст. XXIV Междунар. науч.исслед. конкурса. - Ставрополь : [б. и.], 2020. C. $48-53$.

Мороз, Ю. А. Социально-экономическая политика и экологические аспекты в сфере сельского хозяйства как элементы устойчивого развития / Ю. А. Мороз, А. Ю. Плетнева, О.Н.Шарабанова // European Scientific Conference : сб. ст. XVIII Междунар. науч.-практ. конф. : в 2 ч. - Севастополь : Севастопольский государственный университет, 2020. - С. 61-67.

Окружающая среда. Средняя месячная температура воздуха. - Электрон. текстовые дан. - Режим доступа: https://www.gks.ru/folder/11194 (дата обращения: 10.03.2020). - Загл. с экрана.

Распоряжение Правительства РФ от 06.09.2010 № 1485-р «Об утверждении Стратегии социально-экономического развития Северо-Кавказского федерального округа до 2025 года». Доступ из справ.-правовой системы «КонсультантПлюс».

Распоряжение Правительства РФ от 05.09.2011 № 1538-р «Об утверждении Стратегии социально-экономического развития Южного федерального округа до 2020 года». - Доступ из справ.-правовой системы «КонсультантПлюс».

Расчет расстояний между городами. Флагма. Электрон. текстовые дан. - Режим доступа: https://flagma.ru/raschet-rasstoyaniy.html (дата обращения: 10.03.2020). - Загл. с экрана.

Регионы России: социально-экономические показатели. - М. : Росстат, 2019. - 1204 с.

Сабрекова, М. С. Новый подход к пониманию экологической культуры в контексте устойчиво- 
го развития / М. С. Сабрекова // Современный ученый. - 2020. - № 1. - С. 171-177.

Среднедушевые денежные доходы населения. Электрон. текстовые дан. - Режим доступа: https://www.fedstat.ru/indicator/57039 (дата обращения: 10.03.2020). - Загл. с экрана.

Указ Президента РФ от 13.05.2000 № 849 «О полномочном представителе Президента Российской Федерации в федеральном округе». Доступ из информ.-правового портала «Гарант.ру».

Федеральные выборы: процент за победившего кандидата. Статистика по России. - Электрон. текстовые дан. - Режим доступа: https:// russia.duck.consulting/maps/251/2018 (дата обращения: 10.03.2020). - Загл. с экрана.

Федеральные выборы: явка. Статистика по России. Электрон. текстовые дан. - Режим доступа: https://russia.duck.consulting/maps/252/2018 (дата обращения: 10.03.2020). - Загл. с экрана.

Число учреждений социальной помощи для лиц без определенного места жительства и занятий. Электрон. текстовые дан. - Режим доступа: https://www.fedstat.ru/indicator/41598 (дата обращения: 10.03.2020). - Загл. с экрана.

\section{REFERENCES}

Ablyakimova L.R. Kriterii otsenki ustoychivogo razvitiya [Criteria for Assessing the Sustainable Development]. Ekonomika $v$ teorii $i$ na praktike: aktualnye voprosy $i$ sovremennye aspekty: sb. st. III Mezhdunar. nauch.-prakt. konf. (g. Penza, 25 yanvarya 2020 g.) [Economics in Theory and in Practice: Current Issues and Modern Aspects. Collection of Articles of the III International Scientific and Practical Conference (Penza, January 25, 2020]. Penza, [s.n.], 2020, pp. 49-51.

Avanesov E.K. Kachestvo zhizni i standartizatsiya indikatorov ustoychivogo razvitiya [Quality of Life and Standardization of Indicators of Sustainable Development]. Ekonomika kachestva [Economics of Quality], 2014, no. 1(5), pp. 11-22.

Achokh Yu.R. Ustoychivoe razvitie prirodnoekonomicheskikh sistem [Sustainable Development of Natural-Economic Systems]. Innovatsionnaya traektoriya razvitiya sovremennoy nauki: stanovlenie, razvitie, prognozy: sb. st. Mezhdunar. nauch.-prakt. konf. (g. Petrozavodsk, 2 fevralya 2020 g.) [Innovative Trajectory of Modern Science: Formation, Development, Forecasts. Collection of Articles of the International Scientific and
Practical Conference (Petrozavodsk, February 2, 2020)]. Petrozavodsk, Novaya nauka Publ., 2020, pp. 59-63.

Baybulatova R.Z. Ustoychivoe razvitie v usloviyakh novoy industrializatsii ekonomiki [Sustainable Development in the New Industrialization of the Economy]. Innovatsionnoe razvitie nauki $i$ obrazovaniya: sb. st. IXMezhdunar. nauch.-prakt. konf.: v 2 ch. (g. Penza, 12 yanvarya 2020 g.) [Innovative Development of Science and Education. Collection of Articles of the ${ }^{9^{\text {th }}}$ International Scientific and Practical Conference. In 2 Parts (Penza, January 12, 2020)]. Penza, [s.n.], 2020, pp. 29-33.

Belorusova N.L. Kachestvo zhizni kak faktor ustoychivogo razvitiya regiona [Quality of Life as a Factor of Sustainable Development of the Region]. Ekonomika. Biznes. Finansy [Economy. Business. Finance], 2018, no. 11, pp. 9-13.

Dolya grazhdan, polozhitelno otsenivayushchikh sostoyanie mezhkonfessionalnykh otnosheniy [Share of Citizens Who Positively Assess the State of Interfaith Relations]. URL: https:// www.fedstat.ru/indicator/50995 (accessed 10 March 2020).

Dolya grazhdan, polozhitelno otsenivayushchikh sostoyanie mezhnatsionalnykh otnosheniy [Share of Citizens Who Positively Assess the State of Interethnic Relations]. URL: https:// www.fedstat.ru/indicator/50996 (accessed 10 March 2020).

Zomonova E.M. Ponyatiya i printsipy «zelenoy» ekonomiki [Concepts and Principles of Green Economy]. Ulan-Ude: Ekonomicheskie nauki Publ., 2016, pp. 13-17.

Tretyakova E.A., Mirolyubova T.V., Myslyakova Yu.G., Shamova E.A. Metodicheskiy podkhod k kompleksnoy otsenke ustoychivogo razvitiya regiona $\mathrm{v}$ usloviyakh ekologizatsii ekonomiki [Methodical Approach to Integrated Assessment for Sustainable Development of the Region in Terms of Greening the Economy]. Vestnik UrFU. Seriya: Ekonomika i upravlenie [Urfu Bulletin. Series: Economics and Management], 2018, vol. 17, no. 4, pp. 651-669.

Meshcheryakova Zh.V. Prostranstvenno-dinamicheskie modeli prognozirovaniya ustoychivogo razvitiya selskogo khozyaystva regiona [SpatialDynamic Models of Forecasting Sustainable Development of Agriculture in the Region]. Luchshaya nauchno-issledovatelskaya rabota 2020: sb. st. XXIV Mezhdunar. nauch.-issled. konkursa [Best Research Paper 2020. Collection of Articles of the $24^{\text {th }}$ International Research Competition]. Stavropol, [s.n.], 2020, pp. 48-53.

Moroz Yu.A., Pletneva A.Yu., Sharabanova O.N. Sotsialno-ekonomicheskaya politika i 
ekologicheskie aspekty $\mathrm{v}$ sfere selskogo khozyaystva kak elementy ustoychivogo razvitiya [Socio-Economic Policy and Environmental Aspects in the Field of Agriculture as Elements of Sustainable Development]. European Scientific Conference: sb. st. XVIII Mezhdunar. nauch.-prakt. konf.: v 2 ch. [European Scientific Conference. Collection of Articles of the $18^{\text {th }}$ International Scientific and Practical Conference. In 2 Parts]. Sevastopol, Sevastopolskiy gosudarstvennyy universitet, 2020, pp. 61-67.

Okruzhayushchaya sreda. Srednyaya mesyachnaya temperatura vozdukha [Environment. Average Monthly Air Temperature]. URL: https://www. gks.ru/folder/11194 (accessed 10 March 2020).

Rasporyazhenie Pravitelstva RF ot 06.09.2010 № 1485-r «Ob utverzhdenii Strategii sotsialnoekonomicheskogo razvitiya SeveroKavkazskogo federalnogo okruga do 2025 goda» [Order of the Government of the Russian Federation of September 6, 2010 no. 1485-p "On the Approval of the Strategy of Socio-Economic Development of the North Caucasus Federal District Until 2025"]. Access from Reference Legal System "KonsultantPlyus".

Rasporyazhenie Pravitelstva RF ot 05.09.2011 № 1538-r $« \mathrm{Ob}$ utverzhdenii Strategii sotsialnoekonomicheskogo razvitiya Yuzhnogo federalnogo okruga do 2020 goda» [Order of the Government of the Russian Federation of September 5, 2011 no. 1538-p "On the Approval of the Strategy of Socio-Economic Development of the North Caucasus Federal District Until 2020"]. Access from Reference Legal System "KonsultantPlyus".

Raschet rasstoyaniy mezhdu gorodami. Flagma [Calculation of Distances Between Cities. Flagma]. URL: https://flagma.ru/raschetrasstoyaniy.html (accessed 10 March 2020).
Regiony Rossii: sotsialno-ekonomicheskie pokazateli [Russian Regions: Socio-Economic Indicators]. Moscow, Rosstat, 2019. 1204 p.

Sabrekova M.S. Novyy podkhod k ponimaniyu ekologicheskoy kultury $\mathrm{v}$ kontekste ustoychivogo razvitiya [New Approach to Understanding Environmental Culture in the Context of Sustainable Development]. Sovremennyy uchenyy [Modern Scientist], 2020, no. 1, pp. 171-177.

Srednedushevye denezhnye dokhody naseleniya [Average Per Capita Income of the Population]. URL: https://www.fedstat.ru/indicator/57039 (accessed 10 March 2020).

Ukaz Prezidenta RF ot 13.05.2000 № 849 «O polnomochnom predstavitele Prezidenta Rossiyskoy Federatsii v federalnom okruge» [Decree of the President of the Russian Federation of May 13, 2000 no. 849 "On the Plenipotentiary Representative of the President of the Russian Federation in the Federal District"]. Informacionno-pravovoj portal Garant [Information and legal portal Garant]. Access from "Garant" informational and legal web portal. Federalnye vybory: protsent za pobedivshego kandidata. Statistika po Rossii [Federal Elections: Percentage for the Winning Candidate. Statistics for Russia]. URL: https://russia. duck.consulting/maps/251/2018 (accessed 10 March 2020).

Federalnye vybory: yavka. Statistika po Rossii [Federal Elections: Turnout. Statistics for Russia]. URL: https://russia.duck.consulting/ maps/252/2018 (accessed 10 March 2020).

Chislo uchrezhdeniy sotsialnoy pomoshchi dlya lits bez opredelennogo mesta zhitelstva i zanyatiy [Number of Social Assistance Institutions for Persons Without a Certain Place of Residence and Occupation]. URL: https://www.fedstat.ru/ indicator/41598 (accessed 10 March 2020).

\section{Information About the Author}

Misak S. Arzumanyan, Candidate of Sciences (Economics), Associate Professor, Department of State, Municipal Management and Personnel Policy, Institute of Economics and Agribusiness Management, Krasnoyarsk State Agrarian University, Prosp. Mira, 90, 660049 Krasnoyarsk, Russian Federation, info@kgau.ru,misak-arz@mail.ru, https://orcid.org/0000-0002-9752-7612

\section{Информация об авторе}

Мисак Спартакович Арзуманян, кандидат экономических наук, доцент кафедры государственного, муниципального управления и кадровой политики Института экономики и управления АПК, Красноярский государственный аграрный университет, просп. Мира, 90, 660049 г. Красноярск, Российская Федерация, info@kgau.ru, misak-arz@mail.ru, https://orcid.org/0000-0002-9752-7612 